\title{
Unionization and European antidumping protection
}

\author{
By Hylke Vandenbussche ${ }^{\star}$, Reinhilde Veugelers ${ }^{\star} \uparrow$, and Jozef \\ Konings ${ }^{\star}$ \\ ${ }^{\star}$ Catholic University of Leuven and CEPR London \\ $\uparrow$ Catholic University of Leuven (KULeuven), Naamsestraat 69, 3000 Leuven, \\ Belgium, reinhilde.veugelers@econ.kuleuven.ac.be
}

\begin{abstract}
In recent decades, the WTO has resulted in a worldwide reduction of tariffs and VERs. Instead a new type of trade policy has emerged in the form of antidumping measures. In principle their use should be limited to instances of unfair foreign imports. However, even without unfair pricing, a foreign importer can fall within the scope of the European antidumping legislation. The purpose of this paper is to analyze the interaction between unionization and the likelihood, type and effects of antidumping measures. We present a simple theoretical model which is well embedded in EU legal practice, to show that the presence of European unions leads to an increase in both the likelihood and the level of antidumping protection. In addition our results indicate that a cost asymmetry in the form of a unionized wage differential can alter the relative probability of a duty versus an undertaking. These effects depend on the intensity of product market competition. The paper concludes with some evidence from EU antidumping cases between 1985-95.
\end{abstract}

\section{Introduction}

The principal objective of the World Trade Organization (WTO) is to lower trade barriers between member countries. This is based on the solid economic idea that the removal of trade barriers will stimulate trade and lead to an increase in countries' welfare. One of the most noticeable exceptions to free trade under the current WTO Agreements are the antidumping (AD-) measures which the European Union often applies to protect its industries from foreign imports. The use of $\mathrm{AD}$-measures is defended on the basis of safeguarding fair competition. However, in this paper we show that even in the absence of any kind of unfair competition, foreign importers can be subject to European $\mathrm{AD}$-measures as a result of a cost asymmetry between European and foreign firms. AD-measures resulting from cost asymmetries interfere with the normal course of competition. Thus it is fair to say that $\mathrm{AD}$-measures are in fact a tool of industrial policy which generate rents for domestic firms and alleviate them from tough but not necessarily unfair price competition at the expense of EU consumers who are paying higher prices.

In this paper, we show that high labour costs and strong labour unions which characterize the European industries applying for $\mathrm{AD}$-protection, will affect the 
nature and impact of trade policy, at least in imperfectly competitive markets. Under the current $\mathrm{AD}$-practice, the bargaining power of a labour union in a European firm, will affect the level of price-undercutting and injury and hence the degree of protection from foreign imports that can be obtained. Bargaining power also affects the type of $\mathrm{AD}$-protection as well as the welfare effects from $\mathrm{AD}$ intervention.

While the presence of unions is not the only possible type of cost asymmetry between the EU and its trading partners, wage differences with the EU and union bargaining strength appear to be empirically relevant for industries involved in EU AD-cases. For instance, most countries accused of dumping in the EU between the years 1985-95, with the exception of Japan, were the low-wage countries of South East Asia and Central and Eastern Europe (Vandenbussche, 1996).

Although there is some related literature on the relationship between unions and international trade policy aspects, ${ }^{1}$ none of it however deals specifically with unions and antidumping measures. Where other models have explored the effect of antidumping policy on union-firm negotiations (Brander and Spencer,1988; Mezzetti and Dinopoulos, 1991), we analyze how the presence of unions in a European firm affects the level and the type of antidumping intervention.

In view of the European antidumping law's focus on price comparisons between firms, we analyze the effects of unions on trade policy under differentiated Bertrand competition. By varying the degree of product differentiation, we proxy for the effects of intensity of competition. Only effects on EU anti-dumping policy and EU welfare are considered, ignoring issues relating to the foreign market.

The next section first explains European antidumping rules before we turn to the modeling of these rules. Section 3 discusses the main results, focusing on the impact of union induced cost asymmetries on the level and type of AD-intervention. In Section 4 we present tentative empirical evidence of the relationship between union strength and antidumping protection based on Belgian firm level data. Section 5 sums up the main conclusions.

\section{Theoretical framework}

\subsection{European antidumping rules}

European AD-law stipulates that 'when a foreign firm is dumping its products on the European market thereby causing injury to a European industry, the European government is allowed by the WTO to impose protectionist measures on foreign imports to eliminate the injury, provided it is in the European Community's interest to do so' (EU regulation 384/96).

Hence basically three conditions are required before European protection can apply. The first one involves dumping. Legally, dumping occurs when 'the foreign export price to the European Union is lower than the price at which a product is

\footnotetext{
${ }^{1}$ See Brander and Spencer, 1988; Mezzetti and Dinopoulos, 1991; and Gaston and Trefler, 1995.
} 
sold in the local foreign market'. From an economic point of view it is generally felt that the legal definition of dumping is too wide. ${ }^{2}$ This flaw has been pointed out elsewhere (Tharakan, 1991; Bhagwati, 1988) which is why we do not explicitly model the foreign market. We assume dumping in the legal sense to prevail.

The focus in this paper lies on the second requirement in the EU AD-law namely that the European industry applying for protection has to be injured. ${ }^{3}$ In European $\mathrm{AD}$-cases this injury margin is based on the level of foreign price-undercutting in the European market (Vermulst and Waer, 1991; Veugelers and Vandenbussche, 1999). In other words, when the price at which the foreign 'like product' is sold in the European market is lower than the European price, this price difference is regarded by the EU Commission as the injury margin. Case evidence has revealed that in the majority of European cases, AD-protection is largely aimed at offsetting injury (Messerlin, 1989). This implies that the level of EU antidumping protection is determined by the level of price-undercutting.

A last condition which needs to be checked by European officials is whether the imposition of $\mathrm{AD}$-measures is in the interest of the Community. This Community Interest Clause is generally regarded to correspond with economists' notion of welfare. A welfare function commonly used in issues relating to trade policy consists of European profits, consumer welfare as well as labour interests and in the case of duty protection, government revenue (see for example Mezzetti and Dinopoulos, 1991).

When the EU government decides on protection, either a duty or a price-undertaking is imposed. The purpose of these antidumping measures is to offset the injury. This implies that antidumping measures are constructed for the purpose of eliminating price-undercutting in the EU market which would prevail without them. The underlying idea is that foreign competitors should 'meet' the European competition by setting the same price. A duty is like a tariff, while a price-undertaking is a commitment by the foreign firm to align on the price set by the foreign firm. ${ }^{4}$

\subsection{The model}

The purpose of European Antidumping law is to regulate foreign importers' pricing behaviour. To consider the effects of European unionization on European

\footnotetext{
${ }^{2}$ All types of international price-discrimination classify as dumping in the legal sense. Common reasons for dumping are: a higher elasticity of demand in the export market than in the local market, inflexible factor markets and demand uncertainty (Ethier, 1982), production and demand uncertainties in the local market (Hillman and Katz, 1986), in the export market (Davies and McGuiness, 1982) or in both the local and export market (Das, 1992), learning economies in production (Dick, 1991; Gruenspecht 1988) and spatial pricing policies (Thisse and Vives, 1988).

${ }^{3}$ This injury requirement plays a bigger role in the EU than in the US AD-law. In the US, AD-measures have to offset the dumping margin, while in the EU they have to offset the lower of dumping and injury margin.

${ }^{4}$ This commitment is assumed to be binding given that the Commission closely monitors the priceundertaking and in case of violation, can impose a penalty (EU regulation 386/94).
} 
antidumping protection, we use a simple model. The model consists of one EU firm selling locally and one foreign firm exporting to the EU market. ${ }^{5}$ Demand for the European $(q)$ and the foreign firm $\left(q^{*}\right)$ in the EU market are given by

$$
\begin{aligned}
q & =h+k \cdot p^{*}-p \\
q^{*} & =h+k \cdot p-p^{*}
\end{aligned}
$$

In (1), $p$ refers to the price of the European product and $p^{*}$ refers to the price of the foreign product in the European market. The parameter $h$ indicates market size and the parameter $k$ measures product differentiation and product market competition between the domestic and the foreign product sold in the EU. For $k=0$, products are independent and product market competition is absent. While for $k$ close to 1 products are very similar and competition is tougher. We assume cross-price effects to be smaller than own price effects $(0 \leqslant k<1)$.

The European firm is unionized while the foreign firm is not. The unionized European firm and the foreign exporting firm compete in prices in the EU product market. The European firm's profits are $\pi=(p-w) \cdot q$ and for the foreign firm $\pi^{*}=\left(p^{*}-w^{*}\right) \cdot q^{*}$. In the absence of a domestic union, the EU wage is equal to the foreign wage which we assume to be zero $\left(w=w^{*}=0\right)$. In the presence of a domestic union, the $\mathrm{EU}$ wage $w$ is determined through a Nash bargaining process between the union and the EU firm. This wage bargaining occurs before the domestic and foreign firm compete in the EU product market. Bargaining results in a cost asymmetry between the EU and the foreign firm $\left(w>w^{*}=0\right)$. Our basic results are independent of the type of union utility function. Therefore we turn to a commonly used one, of the form

$$
U(w, L)=w \cdot L
$$

European employment is indicated by $L$ and determined by the EU firm in the product market competition stage of the model (right-to-manage model). A very simple production function is assumed where one labour unit $(L)$ is required to produce one unit of domestic output $(q)$. Without loss of generality we can set the threat points of the union and the domestic firm equal to zero (Binmore et al., 1986). Solving for the bargaining problem then implies maximizing the Nash product consisting of union utility and European profits

$$
\operatorname{Max}_{w} \Omega=(U)^{\beta} \cdot(\pi)^{(1-\beta)}
$$

The parameter $\beta$ in (3) refers to the Union's bargaining strength $(0 \leqslant \beta \leqslant 1)$. The situation $\beta=0$ represents the absence of a union when all product market rents accrue to the domestic firm. The other extreme case where $\beta=1$, is the 'monopoly union' case where the union sets the wage unilaterally (Booth, 1995).

\footnotetext{
${ }^{5}$ The entry/export decision of the foreign firm is not modeled explicitly. Only parameter values are considered for which (free trade) foreign exports are profitable. Also ignored is the possible influence of anti-dumping measures on the foreign firm's mode of entry, cf. the tariff jumping investment literature (e.g. Motta, 1992; Belderbos, 1997). Furthermore we assume that the market structure is given. The implicit assumption here is the presence of a sunk cost of entry.
} 
In Section 3 we will discuss the results of European $\mathrm{AD}$-intervention for varying levels of $\beta$ in more detail.

\subsection{The free trade case: the absence of $\mathrm{AD}$-intervention}

To ease exposition of AD-intervention, we discuss the model in different steps. We first consider the 'Free Trade' case. In a next step we consider the effects of antidumping protection: a duty versus a price-undertaking. In a final step, we study the EU government's decision on whether to intervene and which measure to impose.

The Free Trade case refers to the situation where the EU firm and union bargain over wages, knowing that no anti-dumping intervention will occur in the product market competition stage. This Free-Trade case allows us to consider when price-undercutting prevails and how the presence of unions affects the scope for price-undercutting $\left(p>p^{*}\right)$ which determines the injury margin in EU $\mathrm{AD}$-investigations. In discussing welfare effects we limit our attention to European welfare $(G)$, leaving aside the foreign firm's market. European welfare in the Free Trade case consists of consumer surplus (CS), European profits $(\pi)$ and union utility $(U)$

$$
G=C S+\pi+U(w, L)
$$

Consumer surplus in (4) is given by the following expression

$$
C S=\frac{q^{2}}{2}+\frac{q^{* 2}}{2}+k \cdot q \cdot q^{*}
$$

The expressions for the equilibrium free trade prices and the equilibrium domestic wage levels $w$, arising from the Nash bargaining stage, can be found in Appendix 1 .

In the absence of a cost asymmetry $(\beta=0)$ between the European and foreign firm, wages and prices across firms are the same. With the introduction of a home union, product market rents go in part to the union in the form of a wage level above the alternative wage. This drives a wedge between the European wage $(w)$ and the foreign wage $\left(w^{*}=0\right)$. This cost asymmetry results in a European price that is higher than the price for the foreign product in the EU market $\left(p>p^{*}\right)$. Hence a positive union bargaining power $\beta$ results in foreign price-undercutting. This leads to the following welfare effects:

Proposition 1 The effects of higher union power in Europe under free trade are: a reduction in European profits, consumer welfare and total European welfare but an increase in Union welfare.

Proof See Appendix 2.

\subsection{AD intervention: duties and price-undertakings}

When injury through price-undercutting prevails, an $\mathrm{AD}$-investigation can be initiated by the EU firm. The EU government can then decide on protection, either in the form of a duty or in the form of a price-undertaking. The underlying idea is that foreign competitors should meet the European competition by setting 
the same price $\left(p=p^{*}\right)$. Although both types of measures are aimed at equating post-measure prices in the European market, we will show that the welfare implications of a duty are different from those of a price-undertaking.

A duty $(t)$ is like a tariff that increases the cost of the foreign firm per unit shipped towards the EU. The foreign firm's problem in the case of a duty is (for $\left.w^{*}=0\right)$

$$
\underset{p^{*}}{\operatorname{Max}} \pi^{*}=\left(p^{*}-t\right) \cdot q^{*}
$$

The expression for the European firm's objective function does not alter with a duty.

A price-undertaking is a commitment by the foreign firm to align on the domestic price or in other words an agreement to no longer price-undercut the domestic firm which legal practice regards as injury. This implies that with a price-undertaking, domestic and foreign firms maximize their profits under the restriction that prices should be equal after the price-undertaking. With a priceundertaking, the foreign firm agrees to stick to a reaction function of the form $p^{*}=p$. Since the price-undertaking is public information, the domestic firm, knowing the foreign firm's reaction function, becomes the leader in the price setting game. This implies that in the event of a price-undertaking the European firm is solving the following

$$
\underset{p}{\operatorname{Max}} \pi=(p-w) \cdot q \quad \text { s.t. } p=p^{*}
$$

Hence any price set by the domestic firm will be 'met' by the foreign firm. This will result in a price increase by both firms in the market. Price-undertakings are thus a facilitating practice.

The equilibrium prices under Bertrand competition for both AD measures: duty, and price-undertaking are given in Appendix 1. Equilibrium prices and corresponding quantities are used to derive the equilibrium domestic wage $w$, for each of the possible $\mathrm{AD}$ measures. The antidumping duty $(t)$ which eliminates price-undercutting turns out to be a function of the cost asymmetry between the two firms $\left(t=w-w^{*}\right.$ with $\left.w^{*}=0\right)$ where the equilibrium wage of the home country, $w$, further depends on the level of product differentiation $(k)$ and union bargaining power $(\beta)$.

Proposition 2 The duty that eliminates price-undercutting, is increasing in the European union's bargaining power. ${ }^{6}$

Proof See Appendix 2

With a higher bargaining power of the union, not only is there a higher likelihood of protection, but Proposition 2 indicates that there is also a higher level of

\footnotetext{
${ }^{6}$ If instead of focusing on union bargaining power as the source of cost asymmetry, a simple exogenous cost asymmetry would be assumed, a similar result would hold, since the optimal duty is equal to the wage difference between the European and foreign firm $(t=w)$ hence $(\partial t / \partial w=1>0)$.
} 
protection. Other effects of $\mathrm{AD}$-measures in terms of consumer prices, wages and European welfare can be summarized as follows:

Proposition 3 (i) Antidumping measures (duty $t$, price-undertaking) equate prices across products, raise consumer prices in the market and raise European wages in the industry above free trade; (ii) the European price and wage rise is highest in the case of a price-undertaking; (iii) $\mathrm{AD}$-measures raise European profits and Union welfare but lower consumer welfare compared to free trade.

Proof See Appendix 2

\subsection{EU decisions: no measures, duties, price undertakings}

Having analyzed what the impact will be on EU welfare from the EU government intervening through duties and price-undertakings, a final step in the analysis is to study if, when, and how such intervention will prevail. For this purpose we add an initial stage where the European government has to decide on whether and how to protect in the Community's interest being the sum of European consumer surplus $(C S)$, European profits $(\pi)$, union rents $(U(w, L))$ and, in case of duty protection, duty revenue $\left(T=t \cdot q^{*}\right)^{7}$

The European Commission can intervene whenever the foreign price in the EU market turns out to be lower than the price of the European 'like product' in the case of free trade $\left(p>p^{*}\right)$. The Commission then considers the imposition of measures by comparing EU-welfare under protection (duty, price-undertaking) to the free trade level (given by (4)).

Proposition 4 When product markets are imperfectly competitive, an antidumping duty always raises European Welfare above the Free trade level.

Proof See Appendix 2

In contrast to a duty, the welfare comparison with a price-undertaking are ambiguous and depend on the value of $k$. For not too high values of $k$, a priceundertaking always reduces welfare below the free trade level which will be illustrated in Section 3.

\section{Results: antidumping protection in the presence of unions}

3.1 AD-protection with cost asymmetries induced by EU union bargaining power

As shown in Proposition 3, AD-measures, both duties and price-undertakings, are beneficial to the domestic firm and union, but are detrimental to consumers. When

\footnotetext{
${ }^{7}$ Duty revenue, in principle, has to be refunded to the foreign exporter. However, in practice it can last up to ten years before the Commission actually pays the money back. Therefore it is not unreasonable to include tariff revenue $(T)$ in the domestic welfare function.
} 
(a) 'weak' competition

$\mathrm{k}=0.6, \mathrm{~h}=12$

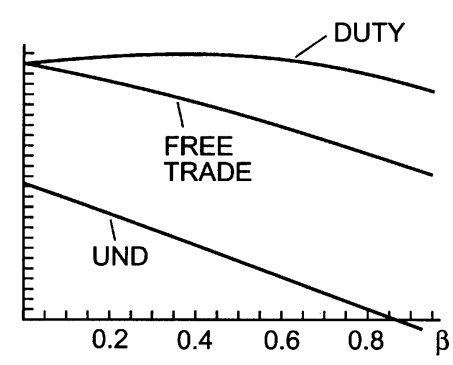

(b) 'strong' competition $k=0.8, h=12$

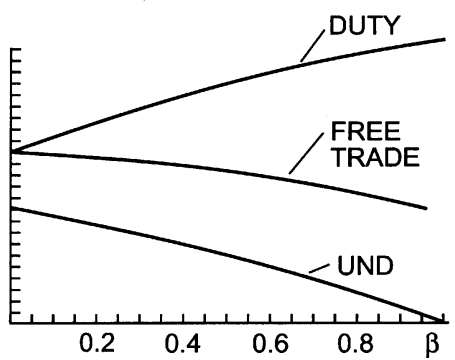

Fig. 1. European welfare

(a) 'weak' competition $\mathrm{k}=0.6, \mathrm{~h}=12$

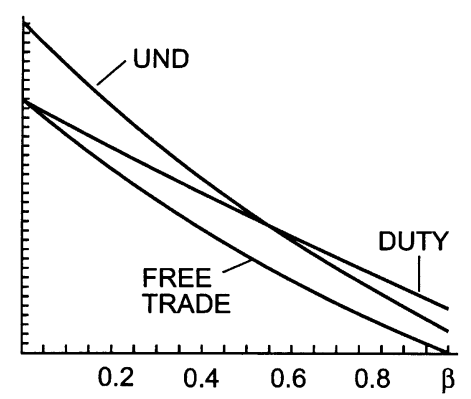

(b) 'strong' competition $k=0.8, h=12$

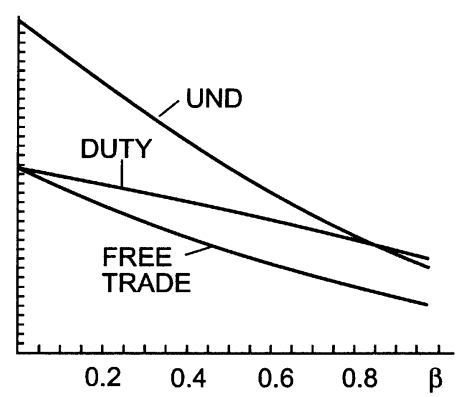

Fig. 2. European firm's profits

the European government decides on intervention, it will want to take the action maximizing the sum of the welfare components. In Fig. 1 we show the welfare in the case of a duty, price-undertaking, and free trade (= no measures) for varying degrees of union bargaining power on the horizontal axis $(0 \leqslant \beta \leqslant 1)$. For $\beta=0$ we are in the extreme case of the absence of unions where wages across firms are equal and no price-undercutting prevails. While for $\beta=1$ we are in the case of a monopoly union. In between these two extremes lie the results for Nash wage bargaining, which lead to higher wages for the European firm than abroad and results in foreign price-undercutting. Since the AD-law stipulates that only foreign 'like products' can be subject to protection, the figures are drawn for relatively similar products, i.e. high levels of the product homogeneity parameter $k$. The left panels of Figs 1 to 3 show the results for a value of $k=0.6$ while the right panels are drawn for a value of $k=0.8$. This will allow us to indicate how product differentiation or alternatively the degree of product market competition affects the results.

For $\beta=0$, there is no foreign price-undercutting and no $\mathrm{AD}$-measures can be taken. It is only when European wages start to exceed foreign wages as a result of 
(a) 'weak' competition $\mathrm{k}=0.6, \mathrm{~h}=12$

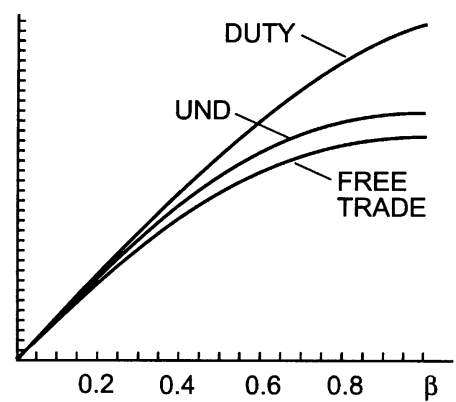

(b) 'strong' competition $\mathrm{k}=0.8, \mathrm{~h}=12$

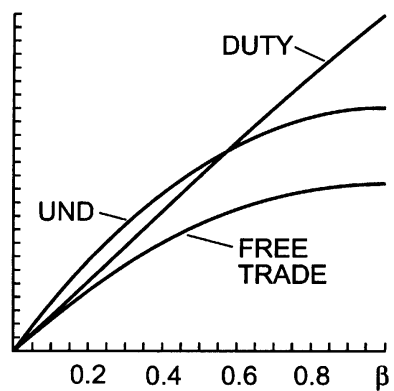

Fig. 3. European union rent

European unionization $(\beta>0)$ that $\mathrm{AD}$-measures can be taken. This can be translated into an empirically testable hypothesis namely:

Hypothesis 1 Union bargaining power in a European sector is positively related to the likelihood of obtaining $\mathrm{AD}$-measures.

With positive $\beta$, an antidumping duty raises European welfare above the Free Trade level, for all values of $\beta$ and $k$ (see Proposition 4). This is illustrated in Figs 1a and $1 \mathrm{~b}$. A price-undertaking lowers European welfare compared to Free Trade for values of $k$ not too close to 1 . Both the detrimental welfare effect of priceundertakings and the beneficial effect of duties are higher when union power is higher. Figures $1 \mathrm{a}$ and $1 \mathrm{~b}$ illustrate that welfare differences become larger when products become more similar (high values of $k$ ). The following hypothesis summarizes a testable hypothesis:

Hypothesis 2 The EU government acting in the Community Interest will typically prefer duties to undertakings, irrespective of union bargaining power. The stronger are unions, the larger the EU welfare increase from duties compared to free trade.

Figure 2 shows the corresponding profits for the European firm. Here we see that the government's preference for a duty does not always coincide with the European firm's preference. For positive values of $\beta$, European profits both in the case of a duty and a price-undertaking are higher than in the Free Trade case. Hence, local producers always gain from intervention. But while the government always prefers a duty, the preference of EU firms for a duty versus a price-undertaking depends on union strength, $\beta$, while also the level of product differentiation, $k$, matters.

When unions are weak, the European firm prefers a price-undertaking to a duty. When unions are strong, local firms will have to share a larger portion of the rents from $\mathrm{AD}$-intervention with the unions, in the form of higher wages. Wage increases, are highest under a price-undertaking (see Proposition 3(ii)). This makes price-undertakings increasingly less attractive to the local firms, compared 
to duties. Once union power is above a critical value, the European firm prefers a duty, which leaves higher profits than price-undertakings, despite lower prices, but due to lower wages. When products are more differentiated and the product market competition is weaker (smaller $k$ ), the critical value of union bargaining power that switches the preference of EU firms from price-undertakings to duties is smaller. Hence, with weaker competition, there is a higher likelihood that European profits are largest under a duty.

Figures $3 \mathrm{a}$ and $\mathrm{b}$ show that the union's preference regarding the type of $\mathrm{AD}$ measures is similar to that of the European firm. When the union is weak (small $\beta$ ) and competition is strong, it prefers price-undertakings, while a strong union prefers duties. The critical value of union power that induces unions to switch to duties, is smaller than the critical value for the EU firms, which implies that unions will prefer duties sooner for already lower levels of bargaining power than EU firms. As product market competition gets weaker (smaller $k$ ), the union's preference of duties over price-undertakings holds independent of bargaining strength.

The result that both the European firm and the union prefer price-undertakings when union bargaining power is weak, and both prefer duties when union bargaining power is strong, is especially relevant when we leave aside the Community Interest assumption. A critique is that the European government often ignores consumers' interests and limits itself to the interests of European producers and unions if only because of the stronger lobbying of firms and unions. From Figs 2 and 3 it becomes clear that when the EU would only act in the interest of local producers and/or local unions, a price-undertaking will be decided upon when unions are weak. When union bargaining power is strong however, the EU government with a limited welfare function would decide on a duty which is welfare superior from a Community interest point of view. When product market competition is strong because products are more homogeneous, the level of bargaining power inducing a switch from price-undertakings to duties is higher. Hence, we expect to see duties instead of undertakings more easily in weakly competitive markets.

This gives rise to the following two hypotheses:

Hypothesis 3 To observe Price-Undertakings suggests that the European government uses a limited welfare function where consumers' interests are ignored.

Hypothesis 4 Under a restricted government welfare function we expect to see less Price-Undertakings and more Duties when union power is strong and product market competition is low (products are more differentiated).

Price-undercutting or 'injury' in the legal sense can also occur but as a result of an exogeneous cost or demand asymmetry instead of a union induced cost asymmetry. Exogenous asymmetries lead to similar welfare effects. The main difference between $\mathrm{AD}$-protection arising as a result of an exogeneous asymmetry versus an endogeneous cost asymmetry, relates to the European firm's preference over the type of $\mathrm{AD}$-measure. In the case of an exogeneous asymmetry, European firm's 
profits are always highest under a price-undertaking while with an endogenous cost asymmetry the European firm's preference between a duty and a price-undertaking depends on the power of European unions, with whom EU producers have to share the rents from protection.

\subsection{Strategic actions to induce $\mathrm{AD}$-intervention}

In an extended framework, the prospect of injury margin protection could induce home and foreign firms to act strategically in the EU market. These strategic incentives arising as a result of antidumping policy have typically been studied in two period models, with one period before and one period after protection (see Fischer, 1992; Prusa, 1994; Pauwels et al., 1997). An antidumping duty, aimed at offsetting price-undercutting, has been shown to induce both home and foreign firms to charge higher prices in the first period as compared to the free trade case (Pauwels et al., 1997). By pulling up its first period price, the home firm seeks to obtain a higher level of duty protection in the second period, while the foreign firm pulls up its first period price in order to reduce the second period level of antidumping protection.

While an extended framework lies outside the scope of the present paper, the model used here allows us to discuss the benefits from $\mathrm{AD}$ interventions for all parties involved, including the domestic firms, unions and the foreign firm. Benefits from intervention can be considered as the prize that can be acquired from deploying strategies to induce EU government to intervene. Parties are willing to incur costs to finance such strategies, up to the level of benefits from intervention. As such, our results allow us to discuss the scope for strategic AD-behaviour.

Since the gains from $\mathrm{AD}$ intervention for the EU firm are most pronounced when competition is weak and union bargaining power is low, the results reported supra suggest that intervention inducing strategies by EU firms are more likely to prevail in these circumstances. Since also unions are benefiting from $\mathrm{AD}$, they too have an incentive for strategic actions inducing $\mathrm{AD}$ intervention and the more so, the more bargaining power they have. But also the foreign firm will not necessarily act myopically. The incentives for foreign firms are shown in Fig. 4. In the Free Trade case, the foreign firm gains from stronger EU unions, which increase their cost advantage versus the European industry. While duties reduce foreign profits compared to free trade, price-undertakings however can result in higher foreign profits, at least when union bargaining power is not too strong. Hence, strategic actions by the foreign firm will be aimed at avoiding EU-AD duties. The scope for such actions increases with stronger EU union bargaining power. In case of weak EU-union bargaining power, the firm will use strategic actions aimed at inducing $\mathrm{AD}$-intervention of the price-undertaking kind. Such actions would be perfectly aligned on the domestic firm's interests, since both firms prefer a price-undertaking decision when union bargaining power is weak. The weaker is competition, the more likely that the foreign firm will loose not only from duties, but also from price-undertakings. 
(a) 'weak' competition $\mathrm{k}=0.6, \mathrm{~h}=12$

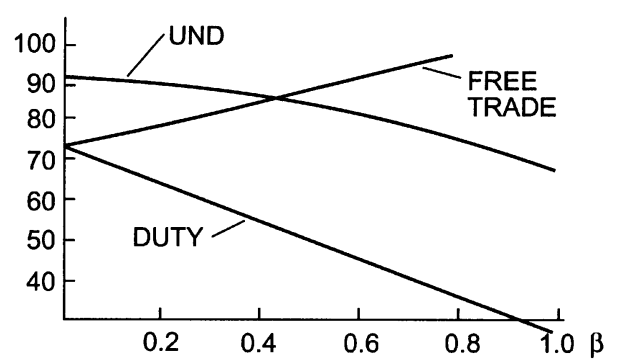

(b) 'strong' competition $\mathrm{k}=0.8, \mathrm{~h}=12$

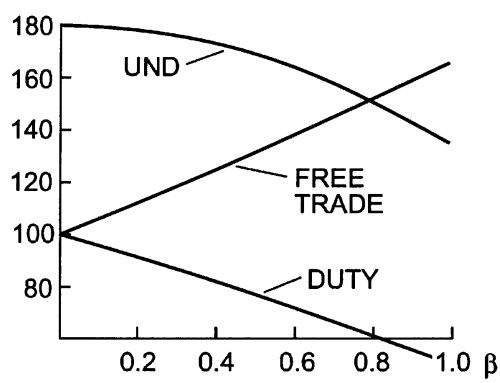

Fig. 4. Foreign profits

\section{Empirical findings}

\subsection{The data}

We use data on all European AD-cases between 1985-95. To investigate the interaction between union bargaining power and $\mathrm{EU} \mathrm{AD}$-actions, we first need to empirically identify the parameter $\beta$ that measures union's strength. A standard way of doing this is by starting from the union bargaining problem in eq. (3) and maximizing with respect to the wage $w$ (e.g. Veugelers, 1989). This implies that

$$
w=w^{a}+\frac{\beta}{1-\beta} \frac{\pi^{o}}{L^{o}}
$$

Thus workers receive the alternative wage $\left(w^{a}\right)$ plus a fraction of the firm's profit per employee $\left(\pi^{o} / L^{o}\right)$. Estimating eq. (8) using firm level data for each sector yields estimates for the industry bargaining power coefficient. Ideally for that purpose we would require data at the European level. Due to the unavailability of sufficiently adequate European company data on employment and wages, we turn to Belgian data and use the estimates of unionization in the relevant industries as proxies for the level of unionization at the European level. This is a serious limitation implying that the results presented in this section should be regarded as tentative evidence. However since Belgium is a small open economy and its labour unions are amongst the strongest in Europe, our exercise can provide interesting insights. We use company accounts data of all Belgian firms for the period 1987-94. Profits per employee $\left(\pi^{o} / L^{o}\right)$ are computed as value added minus labour costs divided by the number of workers and normalized on the consumer price index. The wage $(w)$ is measured as the total labour costs divided by the number of employees in the firm and the alternative wage $\left(w^{a}\right)$ is set equal to zero. ${ }^{8}$ Since there is a potential endogeneity problem in estimating (8), an instrumental variables approach is

\footnotetext{
${ }^{8}$ We experimented with using as the alternative wage the minimum wage in the sector, but this did not change our results.
} 
used. The instruments used include the profit per employee at $t-1$ and year dummies. Appendix 3 shows the estimated bargaining power coefficients, $\beta$, for each NACE-three digit sector in which $\mathrm{AD}$-cases occurred. ${ }^{9}$ The bargaining power for the labour union is estimated on average for all $\mathrm{AD}$-industries at 0.10 , with some sectors having zero bargaining power and the estimated maximum bargaining power is 0.64 . This compares to an average bargaining power of 0.06 (minimum $=0$, maximum $=0.36$ ) for all the other sectors that never experienced ADactions. These results already seem to suggest a positive correlation between the phenomenon of $\mathrm{AD}$ and union power.

As a next step, the bargaining power coefficients were merged with data on anti-dumping cases. AD-measures are reported at the product level (eight digit HS-code). Since the data on bargaining power are at the sector level we had to aggregate the products involved in $\mathrm{AD}$-cases from product to the NACE three digit sector level. Over the period 1985-95 there were 249 EU AD-cases under investigation by the European Commission of which $21 \%$ were terminated without any measures, ${ }^{10} 30 \%$ ended in a price undertaking and $49 \%$ ended in duties (Official Journal of the EC, L-series, 1985-95). As a first observation we note that priceundertakings are frequently used in reality which according to our theory seems to suggest that the EU is using a limited welfare function thereby focusing on European producers' and/or union's interests.

\subsection{The results}

In order to investigate the hypothesis that union bargaining power affects the likelihood of $\mathrm{AD}$-protection, we estimate a probit model. The dependent variable is a dummy equal to 1 if the sector ever experienced an $\mathrm{AD}$ investigation. The results are shown in Table 1 column 1 . We find a positive and statistically significant effect of bargaining power on the probability of filing. This is what we expect as union bargaining power induces a cost asymmetry between the European firm and the foreign firm and hence increases the probability of protection. Because there are many cases where the actual level of protection is not revealed, a formal test of how union bargaining power affects the level of AD-protection is not possible.

We next tested in columns (2)-(4), whether bargaining power affects the type of $\mathrm{AD}$ protection, (duties versus price-undertakings) and whether this varies with the degree of price competition. In table 1, column (2) we report the results of a probit model where the dependent variable takes the value 1 if the case ended with a duty and zero if the case ended with a price-undertaking. ${ }^{11}$ To control for potential

\footnotetext{
${ }^{9} \mathrm{An} \mathrm{AD}$-measure for a particular product applies to all EU members.

${ }^{10}$ A termination occurs when the EU Commission fails to find evidence of dumping or injury or decides it is not in the interest of the Community to impose a measure. In our theoretical model terminations are perfectly anticipated by the domestic firm and no complaint would be filed

${ }^{11}$ Termination cases were ignored in this part of the analysis. Including termination as a third possible case in a multinomial logit regression did not affect the reported results on duties versus undertakings.
} 
Table 1 Results probit regressions

\begin{tabular}{|c|c|c|c|c|c|c|}
\hline Outcome & (1) & (2) & $\begin{array}{l}\text { High } \\
\text { import } \\
(3)\end{array}$ & $\begin{array}{l}\text { Low } \\
\text { import } \\
(4)\end{array}$ & $\begin{array}{l}\text { Low } \\
\text { conc. } \\
(5)\end{array}$ & $\begin{array}{c}\text { High } \\
\text { conc. } \\
(6)\end{array}$ \\
\hline Beta & $\begin{array}{c}1.97^{\star} \\
(1.13)\end{array}$ & $\begin{array}{c}1.67 \dagger \\
(0.85)\end{array}$ & $\begin{array}{c}-1.00 \\
(1.04)\end{array}$ & $\begin{array}{c}7.26 \dagger \\
(1.82)\end{array}$ & $\begin{array}{r}-0.47 \\
(1.47)\end{array}$ & $\begin{array}{c}2.84 \dagger \\
(1.10)\end{array}$ \\
\hline Pseudo $\mathrm{R}^{2}$ & 0.04 & 0.02 & 0.07 & 0.16 & 0.002 & 0.06 \\
\hline
\end{tabular}

Notes: Dependent variable in column (1) is a dummy equal to 1 if there was an AD investigation, 0 else, in all other columns the dependent variable is 1 if the $\mathrm{AD}$ action is a duty, 0 refers to undertaking

Heteroscedastic robust standard errors in brackets, $\dagger^{*}$ stands for statistically significant at the $5 \% / 10 \%$ critical level. All equations include log real GDP per capita as one of the control variables.

cyclical effects we also included the log of real GDP per capita. In column 2 we report a significantly positive coefficient for union power which suggests that higher union bargaining power is associated with more duties and less price-undertakings. This result confirms our theoretical prediction.

To test the differential impact of bargaining power depending on the intensity of product market competition, as Hypothesis 3 suggests, two alternative measures were used and both indicated the same result. The first measure is the Herfindhal index of concentration. The data are classified to the subset of sectors facing low concentration versus the subset of sectors facing high concentration. Sectors with a Herfindhal index lower than 0.20 are classified as sectors facing strong competition. Thus concentration here is taken as a proxy, in the short run, for the degree of competition. The other measure used to classify the data is the degree of import penetration. We classified the sectors that faced higher than average import penetration as those sectors that face strong competition.

Table 1, columns (3)-(6) show the results for the split regression. Column (3) reports the results for those sectors facing high import penetration, while column (4) represents those sectors facing weak import penetration. Likewise column (5) represents sectors with a low concentration ratio, while column (6) shows sectors facing high concentration.

The results indicate that the effect of bargaining power is only statistically significant and positive in the sub-sample where firms face weak competition (columns 4 and 6). Thus irrespective of the proxy that we use to measure the degree of price competition we find that higher union bargaining power increases the probability of duties relative to price-undertakings, but only when competition is weak. Again this empirical result seems to confirm the analysis in the theoretical section. There we found that the critical value of union bargaining power that induces a switch from an undertaking towards a duty decision to be higher when markets are more competitive.

With the average union bargaining power in the sample being 0.10 (with a maximum of 0.64 ) actual union power values are too small to reach critical switching levels in more competitive markets. Only in less competitive markets will actual 
union power vary enough to induce a switch from undertakings to duties with higher bargaining power.

\section{Conclusions}

In this paper we developed a static duopoly model of European antidumping policy. We showed that under the current antidumping rules, labour market imperfections are important in explaining the outcomes and effects of European AD-policy in imperfectly competitive industries. We showed that even without 'unfair' pricing by the foreign firm, antidumping protection can be triggered through the presence of European labour unions. The stronger the wage bargaining power of the European union, the higher the likelihood and the level of antidumping intervention.

Antidumping measures either consist of a duty or a price-undertaking. Our results indicate that when union power is weak, both the European firm and the union prefer a price-undertaking which strongly reduces price competition and yields higher prices and wages than a duty. However, this preference is reversed when unions are strong. A duty raises total $\mathrm{EU}$ welfare compared to free trade while a price-undertaking lowers EU welfare compared to free trade.

In the last section of the paper some tentative empirical evidence on the relationship between union bargaining and the likelihood and type of AD-policy is provided. The evidence suggests that bargaining power positively affects the likelihood of AD-protection. In terms of the type of measures imposed, the empirical results confirm that the higher the bargaining power, the higher the probability that a duty is imposed rather than a price-undertaking.

Before drawing strong policy conclusions further theoretical analysis is required. Further research could include the effects of global market integration and multilateral $\mathrm{AD}$-policies, which were ignored here. Also the assumption of full information between union, government and firms needs to be relaxed. With high stakes for all the parties involved, the possibility of strategic actions to induce the 'right' kind of $\mathrm{AD}$ intervention, should be made explicit. The results obtained in this paper already allowed to identify the direction in which the strategic incentives run by revealing the benefits and/or losses from $\mathrm{AD}$-intervention for each of the players involved.

Despite some of its shortcomings, we believe our analysis to be relevant for policymakers. The findings in this paper clearly contribute to the view that EU $\mathrm{AD}$-legislation, as it stands today interferes with the normal cause of competition and therefore undermines the general purpose and efficiency of the WTO Agreements.

\section{Acknowledgements}

We thank participants in seminars at the University of Bilbao (UPV), Nottingham (CREDIT), EARIE 1997 (KUL), CEPR conference in Barcelona, Cournot Seminar at Paris 
I (Sorbonne). We especially thank Kai-Uwe Kühn, the editors, two anonymous referees for helpful comments, and the VVE (Flemish Association for Economics) for granting the biannual Young Researchers Prize to this paper. The authors are grateful for the financial support provided by the Fund for Scientific Research (FWO).

\section{References}

Belderbos, R. (1997). 'Antidumping and tariff jumping: Japanese firms', FDI in the European Union and US', Weltwirtschaftliches Archiv, 133, 419-57.

Bhagwati, J. (1988). Protectionism, MIT Press, Cambridge, MA, 147.

Binmore, K., Rubinstein, A., and Wolinsky, A. (1986). 'The Nash bargaining solution in economic modelling', Rand Journal of Economics, 17, 176-88.

Booth, A. (1995). The economics of the trade union, Cambridge University Press, New York and Melbourne.

Brander, J. and Spencer, B. (1988). 'Unionized Oligopoly and International Trade Policy', Journal of International Economics, 24, 217-34.

Commission of the EC, Official Journal, several issues of the C and L series between 19851995.

Das, S. (1992). 'Market Uncertainties and cyclical dumping', European Economic Review, 36, 71-82.

Davies. S.W. and McGuiness, A.J. (1982), 'Dumping at less than marginal cost', Journal of International Economics, 12, 169-82.

Dick, A. (1991). 'Learning by doing and dumping in the semiconductor industry', Journal of Law and Economics, 34, 133-59.

Ethier, W. (1982), 'Dumping', Journal of Political Economy, 90, 487-506.

Fischer, R. (1992). 'Endogenous Probability of Protection and firm behavior', Journal of International Economics, 32, 149-63.

Gaston, N. and Trefler, D. (1995). 'Union wage sensitivity to trade and protection: Theory and evidence', Journal of International Economics, 39, 1-25.

Gruenspecht, H. (1988). 'Dumping and dynamic competition', Journal of International Economics, 25, 225-48.

Hillman, A. and Katz, E. (1986). 'Domestic uncertainty and foreign dumping', Canadian Journal of Economics, 19, 403-16.

Messerlin, P. (1989). 'The EC antidumping regulations: a first economic appraisal', Weltwirtshaftliches Archiv, 125, 563-87.

Mezzetti, C. and Dinopoulos, E. (1991). 'Domestic Unionization and Import Competition', Journal of International Economics, 31, 79-100.

Motta, M. (1992). 'Multinational firms and the tariff jumping argument', European Economic Review, 36, 1557-71.

Pauwels, W., Vandenbussche, H., and Weverbergh, M. (1997). 'Strategic Behaviour under European Antidumping rules', Working paper No. 1565, CEPR, London.

Prusa, T. (1994). 'Why are so many antidumping petitions withdrawn?', Journal of International Economics, 33, 1-20. 
Tharakan, M. (1991). The policy implications of Antidumping measures, North-Holland, Amsterdam.

Thisse, J. and Vives, X. (1988). 'On the Strategic Choice of Spatial Pricing Policies', American Economic Review, 78, 122-37.

Vandenbussche, H. (1996). 'Is European Antidumping Protection against Central Europe too high?', Weltwirtschaftliches Archiv, 132, 116-38.

Vermulst, E. and Van Waer, P. (1991). 'The calculation of Injury margins in EC Antidumping Proceedings', Journal of World Trade, 25, 5-42.

Veugelers, R. (1989). 'Wage premia, price cost margins and bargaining power in Belgian Manufacturing', European Economic Review, 33, 169-80.

Veugelers, R. and Vandenbussche, H. (1999). 'European Antidumping Policy and the Profitability of National and International Collusion', European Economic Review, 43/1, $1-28$.

\section{Appendix 1}

\begin{tabular}{|c|c|c|}
\hline Price stage & $\mathrm{p}$ & $\mathrm{p}^{*}$ \\
\hline Free Trade/No intervention & $\frac{2 \cdot(h+w)+k \cdot h}{4-k^{2}}$ & $\frac{2 \cdot h+k \cdot(h+w)}{4-k^{2}}$ \\
\hline \multicolumn{3}{|l|}{ Ad-intervention: } \\
\hline Duty & $\frac{2 \cdot(h+w)+k \cdot(h+t)}{4-k^{2}}$ & $\frac{2 \cdot(h+t)+k \cdot(h+w)}{4-k^{2}}$ \\
\hline Undertaking & $\frac{h+w \cdot(1-k)}{2 \cdot(1-k)}$ & $\frac{h+w \cdot(1-k)}{2 \cdot(1-k)}$ \\
\hline Wage bargaining & w & \\
\hline Free Trade/No intervention & $\frac{\beta \cdot(2 \cdot h+k \cdot h)}{2 \cdot\left(2-k^{2}\right)}$ & \\
\hline \multicolumn{3}{|l|}{ Ad-intervention: } \\
\hline Duty & $\frac{p \cdot(2 \cdot n+\kappa \cdot(n+t))}{2 \cdot\left(2-k^{2}\right)}$ & \\
\hline Undertaking & $\frac{\beta \cdot h}{2-2 \cdot k}$ & \\
\hline \multicolumn{3}{|l|}{ Duty level } \\
\hline
\end{tabular}

\section{Appendix 2}

\section{Proof of proposition 2}

European unionization drives up European wages relative to foreign wages. This cost asymmetry leads to foreign price-undercutting in the EU market and leads to what is regarded as 
'injury to the domestic industry' in $\mathrm{AD}$-cases. The duty aimed at eliminating injury, increases with union bargaining power.

1.1. In the absence of $\mathrm{AD}$-measures, the European wage increases as a result of union bargaining power

$$
\frac{\partial w}{\partial \beta}=\frac{(2+k) \cdot h}{2 \cdot\left(2-k^{2}\right)}>0 \quad \text { for } 0 \leqslant k<1
$$

and so do the consumer prices for the home and foreign product in the European market

$$
\begin{aligned}
\frac{\partial p}{\partial w} & =\frac{2}{4-k^{2}}>0 & & \text { for } 0 \leqslant k<1 \\
\frac{\partial p^{*}}{\partial w} & =\frac{k}{4-k^{2}}>0 & & \text { for } 0 \leqslant k<1
\end{aligned}
$$

Combining (A.2) and (A.1) we also get

$$
\frac{\partial p}{\partial \beta}=\frac{\partial p}{\partial w} \frac{\partial w}{\partial \beta}>0
$$

Combining (A.3) and (A.1) we can show that

$$
\frac{\partial p^{*}}{\partial \beta}=\frac{\partial p^{*}}{\partial w} \frac{\partial w}{\partial \beta}>0
$$

It is now easy to show that bargaining power results in foreign price-undercutting

$$
\frac{\partial\left(p-p^{*}\right)}{\partial \beta}=\left(\frac{\partial p}{\partial w}-\frac{\partial p^{*}}{\partial w}\right) \frac{\partial w}{\partial \beta}>0 \quad \text { since } \frac{\partial p}{\partial w}>\frac{\partial p^{*}}{\partial w}
$$

1.2. The effect of bargaining power on the level of the duty is positive which can be seen from the following $(t=w)$

$$
\frac{\partial t}{\partial \beta}=\frac{2 h \cdot\left(4+2 k-2 k^{2}-k^{3}\right)}{\left(-4+2 k^{2}+k \beta\right)^{2}}>0 \quad \text { for } 0 \leqslant k<1
$$

\section{Proof of Proposition 1}

The effects of European unionization under free trade are: a reduction in European profits, consumer welfare and total European welfare but an increase in Union welfare.

An increase in bargaining power lowers domestic output which can be seen from (A.4) and (A.5)

$$
\frac{\partial q}{\partial \beta}=k \cdot \frac{\partial p^{*}}{\partial \beta}-\frac{\partial p}{\partial \beta}<0 \quad \text { since } \frac{\partial p}{\partial w}>\frac{\partial p^{*}}{\partial w} \quad \text { and } \quad k<1
$$

European profit in the absence of measures are given by

$$
\pi=(p-w) \cdot q
$$

The effect of union power on domestic profits is negative

$$
\frac{\partial \pi}{\partial \beta}=\frac{\partial(p-w)}{\partial \beta} \cdot q+\frac{\partial q}{\partial \beta} \cdot(p-w)<0
$$

The second term in (A.10) is negative as shown in (A.8). In order to see that the first term in (A.10) is also negative we rewrite it as follows

$$
\frac{\partial(p-w)}{\partial \beta}=\frac{\partial w}{\partial \beta} \cdot\left(\frac{\partial p}{\partial w}-1\right)<0
$$


which is negative since $\partial p / \partial w<1$ (see A.2) while $\partial w / \partial \beta$ is bigger than zero (see A.1). Hence both the first and the second term in (A.10) are negative.

In the proof of Proposition 2 we showed that consumer prices in the market go up as a result of unionization. Hence unions lower consumer welfare or $\partial C S / \partial \beta<0$.

The effect of union power on Union rents is positive and given by

$$
\begin{aligned}
\frac{\partial U}{\partial \beta} & =\frac{\partial(w \cdot L)}{\partial \beta} \\
& =\frac{h^{2} \cdot(2+k)(1-\beta)}{2 \cdot\left(4+k^{3}-2 k-2 k^{2}\right)} \geqslant 0 \quad \text { for } 0 \leqslant k<1 \quad \text { and } \quad 0 \leqslant \beta \leqslant 1
\end{aligned}
$$

European welfare as a whole goes down in the presence of unions and in the absence of measures

$$
\frac{\partial G}{\partial \beta}=\frac{h^{2} \cdot(-4(4-\beta)+\Delta)}{2 \cdot\left(4+k^{3}-2 k-2 k^{2}\right)}<0 \quad \text { for } 0 \leqslant k<1 \quad \text { and } \quad 0 \leqslant \beta \leqslant 1
$$

with $\Delta=4 k \cdot(2-\beta)+k^{2} \cdot(20+\beta)-2 k^{3} \cdot(2-\beta)-k^{4} \cdot(6-\beta)>0$

\section{Proof of Proposition 3(i)}

Antidumping measures equate prices across products, raise consumer prices in the market and raise European wages in the industry above free trade.

$\mathrm{An} \mathrm{AD}$-duty raises consumer prices and wages in the European industry above free trade levels

$$
\begin{array}{ll}
\frac{\partial p}{\partial t}=\frac{k}{4-k^{2}}>0 & \text { for } 0 \leqslant k<1 \\
\frac{\partial p^{*}}{\partial t}=\frac{2}{4-k^{2}}>0 & \text { for } 0 \leqslant k<1 \\
\frac{\partial w}{\partial t}=\frac{\beta \cdot k}{4-k^{2}}>0 & \text { for } 0 \leqslant k<1
\end{array}
$$

A price-undertaking also raises consumer prices (both home and foreign) and home wages above free trade $\left(\Delta p=p_{\text {und }}-p_{\mathrm{FT}}\right.$ and $\left.\Delta w=w_{\text {und }}-w_{\mathrm{FT}}\right)$

$$
\Delta p=\frac{h k(4+2 \beta+\Psi)}{4 \cdot(4+\Phi)}>0 \quad \text { for } 0 \leqslant k<1
$$

with $\Psi=-2 k \beta-k^{2}(2-\beta)$ and $\Phi=3 k^{3}-6 k-k^{4}$

$$
\Delta w=\frac{h k \beta}{2(1-k)\left(2-k^{2}\right)}>0 \quad \text { for } 0 \leqslant k<1
$$

\section{Proof of Propostion 3(ii)}

The European price and wage rise is highest in the case of a price-undertaking.

Prices and wages under a price-undertaking are higher than under a duty $\left(\Delta p=p_{\text {und }}-p_{\text {duty }}\right.$ and $\left.\Delta w=w_{\text {und }}-w_{\text {duty }}\right)$. Note that both in the case of a price-undertaking and duty the consumer prices for European and foreign product are the same $\left(p=p^{*}\right)$.

$$
\Delta p=\frac{h k(2-\beta)(2 \beta+\Omega)}{4 \cdot(1-k)(2-k) \Omega}>0 \quad \text { for } 0 \leqslant k<1
$$

with $\Omega=4-2 k^{2}-k \beta$ 


$$
\Delta w=\frac{h k(2-\beta) \cdot \beta}{2(1-k) \cdot \Omega}>0 \quad \text { for } 0 \leqslant k<1
$$

\section{Proof of Proposition 3(iii)}

$\mathrm{AD}$-measures raise European profits and Union welfare but lower consumer welfare compared to free trade.

An $\mathrm{AD}$-duty raises domestic output

$$
\frac{\partial q}{\partial t}=\frac{k}{4-k^{2}}>0 \quad \text { for } 0 \leqslant k<1
$$

Using (A.20), (A.13) and (A.15) we can show that an AD-duty increases the European firm's profits

$$
\frac{\partial \pi}{\partial t}=\frac{\partial(p-w)}{\partial t} \cdot q+\frac{\partial q}{\partial t} \cdot(p-w)>0
$$

From (A.14) and (A.20) it follows that a duty increases Union utility

$$
\frac{\partial U}{\partial t}=\frac{\partial w}{\partial t} \cdot q+\frac{\partial q}{\partial t} \cdot w>0
$$

Consumers loose as a result of protection because prices go up as shown in (A.13 and 14).

What remains to be shown is that European profits and Union rents with a priceundertaking also lie above the free trade levels $\left(\Delta \pi=\pi_{\mathrm{und}}-\pi_{\mathrm{FT}}\right.$ and $\left.\Delta U=U_{\mathrm{und}}-U_{\mathrm{FT}}\right)$

$$
\begin{aligned}
& \Delta \pi=\frac{h^{2} k^{2}(-2+\beta)^{2}}{16(-2+k)^{2}(1-k)}>0 \quad \text { for } 0 \leqslant k<1 \quad \text { and } \quad 0 \leqslant \beta \leqslant 1 \\
& \Delta U=\frac{h^{2} k^{3}(2-\beta) \cdot \beta}{8\left(4+3 k^{3}-6 k-k^{4}\right)}>0 \quad \text { for } 0 \leqslant k<1 \quad \text { and } \quad 0 \leqslant \beta \leqslant 1
\end{aligned}
$$

\section{Proof of Proposition 4}

When product markets are imperfectly competitive, an antidumping duty raises European welfare above the Free Trade level.

Proposition 4 requires that $\Delta G=G_{\text {duty }}-G_{\mathrm{FT}}>0$.

$\Delta G=\frac{h^{2} \beta\left[-16 \cdot \delta^{3} \cdot \xi-48 \cdot \delta^{2} \cdot \beta+4 \cdot \delta^{2} \cdot k^{2} \cdot \beta \cdot(3+k \cdot \alpha)-4 \cdot \mu \cdot \delta \cdot \theta \cdot \beta^{2}+k^{2} \cdot \rho \cdot \beta^{3}\right]}{8 \cdot \lambda^{2} \cdot \delta^{2} \cdot\left(-4+2 k^{2}+k \cdot \beta\right)^{2}}$

$>0$

with

$$
\begin{aligned}
& \delta=-2+k^{2}<0 \\
& \xi=2+k+k^{2}+k^{3}>0 \\
& \alpha=2+k+2 k^{2}>0 \\
& \mu=-2 k+k^{2}<0 \\
& \theta=2+k^{2}+2 k^{3}>0 \\
& \rho=4+3 k^{2}-3 k^{4}>0 \\
& \lambda=-2+k<0 \quad \text { for } 0 \leqslant k<1 \quad \text { and } \quad 0 \leqslant \beta \leqslant 1
\end{aligned}
$$


It can be checked that (A.26) is monotonically increasing in $k$. An easier way to check Proposition 4 is than to consider (A.26) for two extreme values of $k$, zero and 1 , to check that the welfare difference at both extremes is positive

$$
\begin{aligned}
& \left.\Delta G\right|_{k=0}=\frac{h^{2}(256-192 \beta) \beta}{2048}>0 \quad \text { for } 0 \leqslant \beta \leqslant 1 \\
& \left.\Delta G\right|_{k=1}=\frac{h^{2} \beta\left(80-16 \beta-20 \beta^{2}+4 \beta^{2}\right)}{8(-2+\beta)^{2}}>0 \quad \text { for } 0 \leqslant \beta \leqslant 1
\end{aligned}
$$

\section{Appendix 3}

Bargaining power per sector

\begin{tabular}{llll}
\hline NACE (3 digits) & $\boldsymbol{\beta}$ & NACE $(3$ digits $)$ & $\boldsymbol{\beta}$ \\
\hline 221 & 0.11 & 328 & 0.11 \\
222 & 0.47 & 330 & Ns \\
223 & 0.15 & 342 & 0.23 \\
224 & 0.23 & 344 & 0.12 \\
231 & 0.05 & 345 & Ns \\
239 & Ns & 346 & Ns \\
242 & 0.05 & 347 & 0.30 \\
243 & Ns & 363 & Ns \\
245 & Ns & 373 & 0.24 \\
247 & 0.11 & 436 & 0.09 \\
252 & 0.06 & 439 & 0.10 \\
253 & Ns & 451 & 0.64 \\
256 & 0.06 & 455 & Ns \\
257 & Ns & 462 & Ns \\
259 & 0.11 & 466 & 0.21 \\
260 & Ns & 471 & Ns \\
311 & 0.38 & 472 & Ns \\
313 & 0.08 & 481 & 0.14 \\
316 & 0.08 & 483 & 0.06 \\
325 & Ns & 495 & Ns \\
326 & Ns & & \\
& & &
\end{tabular}

Note: Ns stands for not statistically significant; these coefficients were estimated using instrumental variables. 